\title{
Darfur: as várias missões de um conflito complexo*
}

\section{Darfur: the various missions of a complex conflict}

Wellington Pereira Carneiro ${ }^{1}$

${ }^{*}$ Recebido em 17.08.2011

Aprovado em 21.09.2011.

A pedido do autor, a Revista só obteve autorização de publicação em 16.06.2013.

1 Doutor em Relações Internacionais pela Universidade de Brasília- UnB, Mestre em Direitos Humanos pela Universidade de Oxford, Reino Unido, assim como em Direito Internacional Público pela Universidade "Drujby Narodov" em Moscou - Rússia. Graduou-se em Direito pela Univap em São José dos Campos - SP em 1992. Foi coordenador de Programas para América Latina e Caribe da ONG BWI (Building and Wood International); ex-Professor de direito na Univap e de Direitos Humanos no Centro Universitário de Brasília - UniCeub. Atua como Oficial de políticas de Migração e Refúgio para a Ásia Central do Alto Comissariado da ONU para Refugiados - ACNUR em Almaty - Cazaquistão. Foi Oficial de Proteção do ACNUR no Brasil e no Sudão entre 2004 e 2012, e oficial de Emergência para o socorro aos refugiados do Chade na fronteira com Camarões em 2008. As opiniões expressas neste artigo são do autor e não representam qualquer das instituições em que atua ou atuou. Email: wellcarneiro@gmail.com

\section{Resumo}

O Conflito de Darfur constituiu a pior crise humanitária do novo milênio, tendo ocorrido logo após uma época de extrema introspecção da ONU, em que todos os aspectos das missões de paz foram revistos e reavaliados. Sobretudo, após o informe Brahimi, publicado no ano 2000, no qual os revezes em Ruanda, Somália e Bósnia conduziram a revisão do otimismo exacerbado do fim da Guerra Fria. No entanto, a complexidade do conflito de Darfur exigiu um massivo deslocamento de forças e recursos em missões complexas e ousadas. $\mathrm{O}$ artigo explora o gradual retorno às missões complexas, primeiro com missões lideradas por atores regionais, como a AMIS (União Africana) e a EUFOR (União Europeia). Nesse contexto retornam as missões complexas e multifuncionais lideradas pela ONU, incorporando a proteção de populações em risco, direitos humanos e governança, entre outros componentes. Assim, surge a missão hibrida UNAMID e a MINURCAT com mandatos ambiciosos. A UNAMID deve ainda operar simultaneamente à atuação da jurisdição do Tribunal Penal Internacional sobre o conflito em andamento, o que provocará novos desdobramentos e desafios.

Palavras-chave: Darfur. Sudão. Missões de paz. Ajuda humanitária.

\section{Abstract}

The conflict in Darfur represents the worst humanitarian crisis of the new millennium and took place at an extremely introspective time in the UN when all aspects of the peace missions were reviewed and reassessed. Mainly upon release of the Brahimi report published in the year 2000, when the failures in Rwanda, Somalia and Bosnia were conducive to the reassessment of the exaggerated optimism from end of the cold war. However, the complexity of the Darfur conflict demanded again a massive deployment of resources and troops in complex and daring peace missions. This article explores the gradual return to complex operations, first by missions led by regional actors, like AMIS (African Union) and EUFOR (European Union). In this context the complex and multifunctional missions led by the UN return, incorporating the protection of populations at risk, human rights and governance, among other components. That way the hybrid UNAMID and MINURCAT appear with ambitious mandates. The UNAMID has to operate along with the display of the International Criminal Court jurisdiction over an ongoing conflict which will entail new developments and challenges.

Keywords: Darfur. Sudan. Humanitarian. Missions of peace. 


\section{Darfur: uma obscura terra distante e seu con- flito incompreensível?}

29. Conte-lhes a história, tal qual é, daqueles dois filhos de Adão que apresentaram suas oferendas. A oferenda de um foi aceita a outra recusada. Este disse ao seu irmão: vou te matar. - Deus, respondeu o outro, não recebe oferendas mais que dos homens que o temem. (ALCORÃO, SURA V, VERSÍCULO 29)

Esta é a lenda de Quabil e Habil, na Sura V do Corão, que trata do mesmo mito que, no cristianismo, ficou conhecido como Caim e Abel, descrito também no livro do Gênesis, da Bíblia. A certamente ancestral e suposta contradição entre pastores e agricultores, nômades e sedentários foi uma das hipóteses lançadas para tentar explicar um conflito extremamente complexo e de consequências imprevisíveis. A antropologia estuda há anos os sistemas de castas que são gerados pela diferenciação entre pastores e agricultores desde tempos imemoriais. Provavelmente a própria humanidade começou no Sahel, que alberga os fósseis mais antigos de que se tem notícia, nos planaltos da Etiópia, o que alimenta mitos e digressões intelectuais diversas.

Por outro lado, na outra variante explicativa, o conflito de Darfur, longe de contradições ancestrais, é determinado por processos totalmente atuais, ligados ao aquecimento global, e anuncia um futuro de conflitos por escassos recursos, alimentando as catastróficas previsões sobre as futuras "guerras da água". Com efeito, a região do Sahel na qual Darfur se localiza de forma central, situa-se entre o deserto do Saara e a África Tropical, numa extensa faixa que vai do Atlântico, a oeste, até o Golfo de Aden, em sua extremidade oriental. A natureza inclemente, com secas prolongadas e chuvas torrenciais que inundam o deserto de dois a três meses ao ano, inspirou as teses sobre o primeiro conflito do aquecimento global, já que, desde os anos oitenta, as secas são mais prolongadas e as chuvas mais torrenciais. $\mathrm{O}$ ambiente inóspito entre o deserto e a floresta, a diversidade entre o mundo árabe e a África negra, a fronteira entre o Islã e a África Tropical cristianizada ou animista, as rotas ancestrais do deserto e o crescente fundamentalismo se combinam num conflito que, muito provavelmente, gerou o primeiro genocídio do século XXI. Prenúncio de um futuro de conflitos, produto do aquecimento global ou um violento suspiro pré-histórico na hipótese do antagonismo ancestral entre pastores nômades e agricultores sedentários, o conflito de Darfur desafia a compreensão humana. No entanto, talvez uma hipótese bem mais simples baseada nas, igualmente plausíveis, causalidades oriundas das complexas anomalias na formação do Estado Nacional Sudanês, parece fornecer caminhos analíticos seguros, ainda que todos esses elementos, sem dúvida, combinem-se para configurar o mais grave e complexo conflito da atualidade.

No primeiro semestre de 2003, um ataque rebelde a instalações governamentais em $\mathrm{Al}$ Fascher provocou uma violenta reação do governo. Em poucos meses, 200 mil pessoas cruzaram a fronteira do Chade. Os sistemas de alerta não acusaram a possibilidade iminente de crise na região. Ao contrário, o Sudão era motivo de otimismo, uma vez que um longo e sangrento conflito no sul do Sudão se encaminhava para a assinatura de acordos de paz que colocaram um termo a mais de 50 anos de guerra civil com o SPLM/A (Sudan People's Liberation Movement) Army). O conflito de Darfur se desencadeia num momento em que a comunidade internacional já havia desenvolvido uma forte percepção sobre o genocídio. Após o conflito de Ruanda, vinha conduzindo grandes debates sobre a maneira de enfrentá-los. O conflito começa nove anos depois do genocídio de Ruanda, quando se preparava a publicação de um doloroso informe de autocrítica da atuação da ONU em 1994. Em dezembro de 2001, foi publicado o polêmico informe da Comissão Internacional sobre Intervenção e Soberania Estatal, que lança o conceito da "Responsabilidade de Proteger" e provoca o ressurgimento do conceito de intervenção humanitária como teoria e prática nas relações internacionais (ICISS, 2001). A história poderia ter sido diferente em Darfur, mas não o foi. O conflito de Darfur se torna particularmente grave por ocorrer justamente junto ao décimo aniversário do fracasso mais traumático da comunidade internacional no campo das operações humanitárias - genocídio - , e muitos se perguntam por que já teria acontecido de novo.

Em 2005, o Conselho de Segurança obtém um consenso surpreendente sobre a referência da situação de Darfur ao Tribunal Penal Internacional, do qual três dos cinco membros permanentes do Conselho não aderem a ele, nem tampouco o Sudão, o país implicado (ORGANIZAÇÃO DAS NAÇÕES UNIDAS, 2005). O governo americano vinha violentamente, e atacando e hostilizando o Tribunal que, surpreendentemente, pela primeira vez, ganha um protagonismo inédito atuando sobre um conflito em andamento de grande repercussão internacional, por referência do Conselho de Segurança. No en- 
tanto, a perspectiva mais imediata de paz para o sul do Sudão, num conflito mais antigo com fontes energéticas em jogo, e a prioridade na "guerra contra o terrorismo", faz com que essa opção seja preferida em relação a tão aclamada intervenção humanitária, que nunca ocorreu.

Os Estados Unidos e a Grã Bretanha, com a guerra ao terror em andamento e com tropas comprometidas em dois conflitos de alta intensidade, as guerras no Afeganistão e Iraque, não tinham interesse por qualquer incerta e custosa intervenção humanitária em lugares remotos (EVANS, 2008). A percepção da fase intervencionista das grandes potências e o histórico de ligações perigosas do Sudão com o fundamentalismo islâmico geram uma relação de profunda desconfiança que termina por gerar a primeira missão hibrida União Africana e Nações Unidas, com o estabelecimento da UNAMID em 2006, com um mandato bastante amplo e que se assemelha a uma proposta de "intervenção humanitária”, porém sem a capacidade de cumpri-lo. Por outro lado, o agravamento sem constrangimentos do conflito leva á regionalização e, praticamente toda a África Central Setentrional é tragada pelo conflito de Darfur. O Chade e a República Centro Africana, pobres e sem recursos, entram em crise securitária, institucional e social diante do contágio do conflito, dilacerando suas porosas fronteiras. Em 2008, entra em operação a EUFOR, a força de paz da Europa para o Chade e República Centro Africana, marcando também profundas mudanças na configuração das missões de paz do pós-guerra fria. Finalmente, no plano tático das operações humanitárias, o transbordamento da crise para o vizinho Chade e para a República Centro Africana coloca importantes desafios técnicos e políticos para o sistema internacional de proteção aos refugiados que se diluem em campos mistos de refugiados e deslocados internos, desafiando os paradigmas de determinação das pessoas protegidas pelo sistema.

Portanto, de forma inédita, no pós-guerra fria, o conflito de Darfur expressa todas as grandes crises paradigmáticas no tratamento das crises humanitárias, tanto no seu aspecto de socorro humanitário como no aspecto de segurança ou institucional. Existe uma inegável tensão entre a tendência à securitização do genocídio, ou seja, tratá-lo como um problema de segurança e responder pela via militar, e a tendência a tratá-lo como um problema do direito internacional e responder institucionalmente por meio da atuação do Tribunal Penal
Internacional. Por outro lado, o colapso da neutralidade da assistência humanitária, do qual Darfur é um marco importante, coloca milhares de pessoas em uma situação de indigência humanitária no limite da sobrevivência física, num momento de entrave da ação internacional, com muitos obstáculos políticos e operacionais para uma intervenção decidida e eficaz em Darfur.

\subsection{Antecedentes históricos}

A história da constituição do Estado Sudanês está marcada por dicotomias culturais e ancestrais na fronteira do mundo árabe com a África Subsaariana. Na modernidade, a formação do establishment político sudanês se dá em meio ao crescimento de duas tendências políticas regionais e centrífugas que se combinam de forma dinâmica, as quais têm seu centro de formação no Egito, tradicionalmente um centro cultural e político do mundo árabe, e majoritariamente islâmico. O Egito é o berço tanto do nacionalismo árabe como do fundamentalismo islâmico. A hegemonia dessas duas concepções vai se alternar no desenvolvimento político do Sudão como Estado Nacional em consolidação. No entanto, o território sobre o qual se constitui historicamente o Estado, estava longe de ser a base sólida para a constituição de um Estado árabe e muçulmano devido à sua grande diversidade o que inevitavelmente levaria à assimilação forçada ou ao conflito violento.

A maioria da população de Darfur pertence a etnias africanas, como os Zaghawa, Massalit e Fur; os Beja correspondem a $6 \%$ da população do Sudão (JOHNSON, 2006). Os árabes, a maioria da elite no governo, constituíam 39\% da população (KAROL, 1958, p. 36-37) ao tempo da independência. $O$ árabe é definido como língua oficial, mas fala-se mais de cem línguas, além do Inglês herdado da colonização britânica. A população Darfur constitui um complexo mosaico de muitas etnias, frequentemente sobrepostas e interconectadas. A região central é habitada por tribos de agricultores sedentários como os Fur, Masalit, Tama, Qimr, Mima e outros que falam suas próprias línguas, enquanto que o sul é habitado por tribos que adotaram o árabe como língua e se dedicam ao pastoreio nômade. Os Baqqara; Bani Halba, Habbaniyya, Rizayqat e Taaisha são os grupos mais numerosos. Por isso, o conflito é descrito por meio de duas importantes simplificações: árabes contra africanos e pastores contra agricultores. Na verdade, no Sudão, a diferenciação entre africanos negros e árabes brancos não existe, a miscige- 
nação ao longo dos séculos fez com essa diferenciação tenha, em grande parte, se diluído. A diferenciação entre pastores, sobretudo árabes e agricultores africanos também apresenta ambiguidades. Os árabes trouxeram para a região o comércio e o pastoreio nas longas caravanas que ancestralmente cruzaram o deserto, inclusive nas peregrinações à Meca, mas há povos africanos que também desenvolveram o pastoreio. O sectarismo e a arrogância do monoteísmo, supostamente, culturalmente superior, não se aplicariam ao caso de Darfur islamizado e, historicamente, a constituição de um estado em Darfur antecede em muito os árabes da região central de encontro do Nilo Branco e o Nilo Azul, onde se encontra a capital Cartum e a ancestral Ondurman, que somente constituiu seu primeiro estado após a rebelião liderada por Mohamed Ahmed al-Mahdi entre 1885 e 1898 (WAAL, 2007).

Será a elite árabe de Cartum/Ondurman que, no século XX, refletirá as duas tendências políticas emanadas do Egito no período pós-colonial. Por um lado, o nacionalismo árabe, cuja máxima expressão alcançou Gamal Abdel Nasser inspirando a constituição do movimento palestino e toda uma geração de líderes nacionalistas que desenvolve uma aversão política ao colonialismo ocidental e a Israel em particular. Por outro lado, o vazio deixado pelo nacionalismo árabe, humilhantemente derrotado na Guerra de 1967, é suplantado pelo fundamentalismo islâmico. As tendências fundamentalistas começaram a se desenvolver na península arábica, com o Sultão Muhammad ibn Abd Al-Wahhab (1703-92) e continuou com a resistência à modernização dependente do Egito sob Muhamad Ali (1769-1849), que iniciou o longo estranhamento com a secularização e modernização do Estado. No século XX, Rashid Rida foi o primeiro a propor o ressurgimento de uma espécie de moderno Califato baseado na Sharia. Alimentando-se das contradições entre tradição e modernidade e derrota do nacionalismo, surge na cena política a irmandade islâmica (ARMSTRONG, 2001) nos anos setenta.

Já no Sudão, a guerra interminável no sul, assim como o arabismo exacerbado e o fundamentalismo sectário de parte da elite, aprofunda a alienação entre o centro e os povos do Sudão nas províncias longínquas e abandonadas à própria sorte. O elemento confrontacional comum dessas tendências majoritárias nas elites levou respostas violentas às demandas de inclusão e desenvolvimento das regiões mais deprimidas e, ao contrário do sul, produziu uma ofensiva de violência fratricida inaudita entre os povos muçulmanos de Darfur. No entanto, ao contrário do Sudão, que pouco se reconhece, a identidade cultural e institucional de Darfur é muito clara e antecede a do próprio Sudão.

\subsection{O Darfur independente - o sultanato de Keyra Fur (1640-1916)}

O Sultanato de Darfur data do final do século XIV ou começo do século XV, constituído pelas tribos africanas Dadjo e Tunjur, atualmente de pouca expressão política, mas ainda presentes na região, associadas aos outros grupos majoritários. Pouco restou documentado desse período inicial; no entanto, o sultanato adquiriu forma mais complexa a partir do século XVII, durante o reinado do Sultão Suleiman, que desceu as montanhas de Jebel Marra no centro de Darfur e fundou o que ficou conhecido como o Sultanato de Keyra Fur (PRUNIER, 2007). Os primeiros registros escritos da existência do Sultanato de Darfur datam dessa época, por volta de 1640. A islamização teve um papel fundamental, uma vez que, após o colapso da autoridade dos Tunjur, os Fur unificaram os povos da planície sob a autoridade do Islã, trazendo vários clérigos que aumentaram sua capacidade administrativa por meio da escrita.

Os Fur eram militarmente superiores e culturalmente intolerantes; portanto, os que se recusassem a se converter tinham que partir para o sul. Dessa forma, o Islã se transformou no meio unificador de um estado homogêneo e organizado. Darfur entrou finalmente no mapa da África muçulmana, parte da maior civilização organizada da época, entrando no contexto de uma rede de comércio com os já islamizados sultanatos do Sahel e o Egito ao norte. Darfur passa a fazer parte da Ummah, a sociedade internacional dos crentes do Islã que se expandia até a Ásia. O Islã era a medida de civilização superior que se impunha militarmente, assim como pela escrita e pela religião. A integração linguística e religiosa foi seguida da integração política e econômica. Ao centralizar-se administrativamente, o sultanato submeteu outros que se tornaram tributários e pôde se organizar para as caravanas ao sul, para capturar escravos a serem vendidos a oeste, onde terminariam embarcando na "viagem sem retorno" a partir da ilha de Gorée no Senegal.

Os Zaghawa ao norte e os Massalit a leste e ao sul não estavam sujeitos à escravização por serem igualmente 
islamizados. A diferenciação étnica também continuou a existir; o sultão Mohamad Tayrab (1752-85) era chamado "soberano dos árabes e dos bárbaros", ou seja, daqueles que não falavam o árabe. Portanto, ainda que o sultanato tenha se fundado e fosse administrado a partir dos Fur, o sultão encarnava os valores do "arabismo", como símbolo de civilização superior e sacra: a língua e a cultura de Maomé, o profeta. Em 1821, a sorte de Darfur começa a mudar quando o vice-rei do Egito, Muhammad Ali, lança seus exércitos à conquista dos territórios ao sul da planície do Saara. A cavalaria darfuri não era páreo para as tropas egípcias que possuíam canhões e eram treinadas por ex-oficiais do exército napoleônico. No entanto, Muhammad Ali os derrotou na batalha de Barra em agosto de 1821, mas decidiu não ir adiante e assegurou as rotas comerciais do vale do Nilo e o caminho livre para as caravanas escravistas e para a caça de elefantes ao sul. Os darfuris se retiraram às suas ancestrais fronteiras a oeste. Esse período durou até que os turco-egípcios assegurassem seu controle das rotas do vale do Nilo, quando voltaram a enviar expedições para atacar Darfur. Esse período ficou conhecido como a época dos bandidos e foi enfraquecendo o Sultanato até que o aventureiro Zubeyr, à frente de um exército de escravos, matou o sultão Ibrahim Quarad em 1874 e controlou o sultanato de Keyra. As autoridades coloniais turco-egipcias aproveitaram e capturaram $\mathrm{Zu}$ beyr e conquistaram Darfur (PRUNIER, 2007).

O Sultanato de Keyra, que corresponde atualmente a $80 \%$ do território de Darfur, entrou num período de grande instabilidade com revoltas populares messiânicas, conflitos sucessórios e conquistas externas no marco da expansão colonial. Por ocasião do estabelecimento do consórcio anglo-egípcio, a região foi considerada economicamente irrelevante e, como a definição das fronteiras do Dar Massalit poderia causar tensões com a França empenhada na conquista do Chade, deixaram-na ser governada como um sultanato independente, não sem antes assegurar a lealdade de um sultão pró-Cairo e pró-Londres.

O expansionismo colonial francês foi também decisivo na supressão definitiva da soberania de Darfur. Ali Dinar, o último sultão do Darfur independente, reagiu de tal forma violenta contra as ameaças das revoltas messiânicas que marcaram o período mahadista (ou dos bandidos, como ficou conhecido) que passou a executar sumariamente os pregadores que se declaravam herdeiros desses movimentos religiosos. Avançando pelo oes- te, os franceses haviam estabelecido sultanatos fantoches nas fronteiras orientais, Sila, Dar Tama, Dar Gimr, e Dar Massalit, além de conquistarem Wadai. Quando os franceses foram derrotados pelos Massalits na batalha de El-Geneina, Ali Dinar viu a oportunidade de parar o avanço francês e restabelecer sua autoridade sobre os pequenos sultanatos da fronteira oeste, Dar Sila e Dar Massalit. Finalmente, a eclosão da Primeira Guerra Mundial e o temor dos avanços nas posições turco-germânicas empurraram Darfur para um anexo dos problemas e soluções dos ingleses do condomínio anglo-egípcio por um lado, e os franceses estabelecidos no Chade por outro; as condições históricas para a existência de um sultanato independente em Darfur haviam acabado.

O temor de um alinhamento de Ali Dinar com os turcos selou a supressão de Darfur como entidade política independente (PRUNIER, 2007). Após um ultimato, Ali Dinar foi derrotado em El Fasher e perseguido até as montanhas de Jebel Marra onde caiu, em 16 de novembro de 1916. Na mesma região, o tradicional bastião do século XVII, o primeiro soberano Fur Suleiman desceu da montanha para estabelecer um Sultanato que, no meio do deserto, sobreviveu por 300 anos. No entanto, a perda da soberania foi adsorvida pela região, que voltou aos modos de vida tradicionais, e a maioria dos funcionários do antigo Sultanato foi incorporada pela administração colonial. A ausência de grandes conflitos com a estabilização colonial permitiu a retomada do pastoreio de camelos, gado, cabras e asnos e a continuidade das rotas comerciais pelo Sahel, pelo Chade francês até os mercados de Kano e pelo Kousseri até a África Ocidental. O período colonial e o do Sudão independente foram marcados por uma espécie de letargia benevolente que permitiu à região viver em relativo isolamento aplicando as leis tradicionais para a resolução de conflitos entre os líderes tribais e comunitários, para o manejo das fontes de água, regime de chuvas, divisão de áreas de pastoreio e agricultura e as rotas dos pastores nômades, diante de uma parca presença de um estado central, até os anos 70, quando a realidade começa a mudar. Isso ocorre a partir de três fatores principais: a instabilidade endêmica do Chade, as ambições expansionistas da Líbia do então Presidente Muamar Gaddafi e a grande seca de meados dos anos 80 . O avanço das iniciativas de consolidação do Estado sudanês na região será, então, o detonador do conflito, acumulando fatores que atingem seu ápice no final dos anos noventa. 


\subsection{Mudanças climáticas e conflito em Darfur}

As fronteiras artificiais entre as possessões francesas e inglesas dividiram os povos que, tradicionalmente, conviveram durante séculos interagindo em seus modos de vida e criando uma estabilidade produtiva de subsistência, sem grandes excedentes, mas estável, numa região de escassos recursos naturais. Toda a imensa faixa do Sahel possui clima semelhante, sendo que Darfur se situa, de forma longitudinal, mais ou menos ao meio dessa faixa. Ao norte, o Dar Zaghawa se assemelha ao Saara concentrando o pastoreio ao redor dos oásis e é sujeito a secas prolongadas, sendo habitado também por tribos de pastores árabes. A região central, conhecida como Darfur Oeste, concentra as montanhas de Jebel Marra, sendo mais fértil e mais densamente povoada por populações de etnia Fur, Massalit (Dar Massalit) e Dadjo. O Darfur do Sul possui clima instável e é sujeito a secas e instabilidade de precipitação. No entanto, em geral, o período de seca se prolonga de outubro a maio, e o período de chuvas, de junho a setembro. O debate sobre o papel do clima como fator causal do conflito se dá a partir do papel da seca dos anos oitenta da vida dos povos de Darfur e, posteriormente, no final dos anos noventa, como detonadores de confrontações grupais entre pastores e agricultores em torno do começo das chuvas principalmente nas secas de 1998 e 1999. No entanto, o avanço e retração do deserto é uma realidade ao longo de todo o Sahel. As linhas de precipitação e seca ao norte delimitando com o Saara, por exemplo, variaram entre 1931 e 1960 à altura de Nouakchott na Mauritânia, à altura do paralelo $18^{\circ}$, mas de 1968 a 1997 se reduziram para se situar à altura do paralelo $16^{\circ}$, onde se localiza a cidade histórica de Timbuktu no Mali a mais de $1000 \mathrm{~km}$ da costa atlântica.

Tabela 1 - Seca

\begin{tabular}{c|c|c}
\hline Precipitação anual & $\mathbf{1 9 7 6}$ & $\mathbf{1 9 8 6}$ \\
\hline Kutum & 295 & 197 \\
\hline El-Geneina & 510 & 373 \\
\hline El Fashir & 270 & 162 \\
\hline Zalinguei & 612 & 460 \\
\hline Garsila & 665 & 558 \\
\hline Nyala & 464 & 351 \\
\hline Ed-Da'ein & 486 & 422 \\
\hline
\end{tabular}

Fonte: (WAAL; FLINT, 2008)
Portanto $_{2}$ a faixa ao sul do deserto do Saara e a extensão do Sahel que, delimitando com a zona tropical, pode variar de 50 a $100 \mathrm{~km}$ em um período de duas ou três décadas. A diminuição da faixa de precipitação entre 1976 e 1986 registrou uma contração entre 14 e $40 \%$ em todas as regiões de Darfur.

A grande seca de meados dos anos oitenta, pela sua gravidade e o sofrimento que causou, combinado com a resposta do governo central de Cartum, pode ter tido um efeito desagregador fundamental. A prolongada seca e a grande fome que se seguiu destruíram a eficácia dos mecanismos tradicionais de composição entre as formas de organização social e subsistência, as indenizações, as rotas e épocas de chegada, o nomadismo e o sedentarismo, o pastoreio e a agricultura. A causalidade ambiental do conflito em Darfur pode ser resumida em três tendências sobrepostas: o maior rigor das secas, que obrigaram tribos tradicionalmente nômades a buscarem formas mais sedentárias, causando conflitos por fontes de água e pastagens, assim como áreas e assentamentos considerados por outras tribos como suas terras ancestrais. Logo, a deterioração dos mecanismos de resolução de conflitos, desorganizados na grande seca, é agravada pela introdução de mecanismos não aceitos pelas comunidades, assim como a disponibilidade de armas de fogo modernas que mudaram a forma de conduzir os conflitos, tornando-os mais violentos, culminando com o agravamento da clivagem étnica entre árabes e não árabes nas disputas por escassos recursos naturais (UNIVERSITY FOR PEACE, 2004).

Em Darfur, a partir de 1972, quando se conseguiu uma relativa paz com os cristãos do sul, o isolamento e o abandono de Darfur pareciam ter chances de se reverter. Apesar da relativa autonomia e a nomeação de um governador, a situação ambiental era mais critica a cada ano, com o avanço da desertificação a crescente inutilização de vastas áreas antes cultiváveis, o que forçava os pastores do norte a adotarem um novo modo de vida nômade, avançando sobre pastagens pertencentes aos agricultores sedentários e alimentando conflitos intergrupais. A seca já vinha se anunciando há anos, mas a corrupção do governo de Nimeiry em Cartum distorceu as prioridades e, projetos direcionados a melhorar a infraestrutura hídrica haviam sido desviados, equipamentos para poços como bombas doados pelo Ocidente jaziam em Port Sudan, sem que ninguém se preocupasse em recolhê-los, presos 
na burocracia e na corrupção. As equipes de técnicos em água para as zonas rurais não recebiam salários em dia, careciam de equipamentos e o serviço era precário. No que ficou conhecido como a "carta da fome" em novembro de 1983, o governador de Darfur, Diraige, escreve ao presidente Nimeiry, alertando que, ao menos que se pedisse ajuda alimentar ao exterior, uma grande fome seria inevitável em Darfur em 1984. Nimeiry recusou o pedido, por razões puramente ideológicas, uma vez que havia iniciado um processo de reconciliação política com antigos oponentes e com o Ocidente, que ainda via com desconfiança sua antiga afinidade com o partido comunista.

Após a crise do petróleo em 1973, os países árabes buscaram reduzir sua dependência na importação de alimentos e buscaram o Sudão, com extensão e vastas áreas cultiváveis, como opção para o investimento na agricultura e na produção de alimentos. A propaganda oficial para atrair investimentos dos estados do golfo e do Ocidente retratava o Sudão como celeiro do mundo árabe. A confrontação ao redor da perspectiva de fome ocasionou o exílio de Diraige, que teve sua prisão decretada. No entanto, já em começo de 1984, a FAO alertava para o déficit alimentar em Darfur por 39 mil toneladas. Em agosto de 1984, a fome se espalha pelo Sudão, e cerca de 60 a 80 mil famintos deslocadas migram para Cartum em busca de ajuda alimentar. A situação em Darfur era ainda mais crítica e a região foi declarada "zona de desastre" quando o governo pede 160 mil toneladas em ajuda alimentar. Os Estados Unidos direcionam 250 mil toneladas de ajuda. A instabilidade do Sudão era temida em uma região onde a fome era um fator político, como na comunista Etiópia que alimentava a fome com uma intermitente guerra civil (KISSI, 2003, p. 315-317). No entanto, já era tarde; os preços dos alimentos já haviam subido $33 \%$, e o FMI ameaça suspender o Sudão, devido à sua precária situação financeira.

Um rastilho de rebelião percorre o país e uma greve geral é decretada, ao cabo da qual, depois de vários dias de massivas manifestações e enfrentamentos nas ruas, o governo Nimeiry cai em abril de 1985, sem que os militares tenham se proposto a defendê-lo.

Eleições são marcadas para o prazo de um ano. $\mathrm{O}$ novo governo se aproxima de Gaddafi, que envia grandes comboios de ajuda alimentar através do deserto até Darfur, a mais de dois mil $\mathrm{km}$ ao sul. No entanto, privilegiando seus interesses no Chade, Gaddafi também arma as tribos árabes vistas como seus aliados locais, em suas ambições expansionistas no país vizinho. As consequências da fome, que durou de agosto de 84 a novembro de 85 , não tardaram a se sentir. $\mathrm{O}$ alto preço em vidas humanas, 95 mil em uma população de 3,1 milhões foram sentidos como produto da negligência do governo "árabe" de Cartum. As áreas de cultivo antes abertas começam a ser cercadas, e as rotas dos nômades redefinidas, fazendo-os suportar as piores consequências da fome com a redução de suas rotas e áreas de pastagens. Por outro lado, as tribos árabes, ao norte, foram beneficiadas com a ajuda da Líbia, com o intuito de utilizá-las posteriormente contra o Chade. O fosso se aprofunda, uma vez que o primeiro governador nativo "africano" de Darfur tentou alertar sobre o risco de fome que os "árabes" de Cartum ignoraram.

\subsection{A conexão chadiana, armas leves e arabização em Darfur}

A ajuda líbia de alimentar rapidamente se torna militar. A guerra no sul havia sido retomada em 1983. Um acordo tácito permitiu a continuidade da presença líbia em Darfur, em troca de auxílio para a guerra no sul. No entanto, a população de Darfur manifestava clara oposição ao conflito no sul. Em abril e setembro de 1986, ocorrem deserções massivas e manifestações violentas em Nyala (Sul de Darfur) sendo que duas pessoas morreram e quarenta ficaram feridas. Panfletos foram distribuídos com a seguinte indagação: "por que devemos combater nossos irmãos do sul, não somos iguais?" e os recrutas se recusaram a abordar o trem que os levaria a combater no sul (KISSI, 2003, p. 58). Por outro lado, as tribos árabes tinham sido envolvidas no esforço de guerra contra o Chade. Gaddafi, então presidente da Líbia, tinha 20 mil homens na fronteira preparados para invadir o Chade e anexar a reclamada faixa da Aozou ao norte, em pleno deserto do Saara, e contava com 2000 árabes de Darfur preparados para abrir uma segunda frente, tão logo começasse a ofensiva (AZEVEDO, 1998) O Governo sudanês se assustou com a libianização de Darfur, no entanto, enfraquecido com a guerra no sul, nada pôde fazer, mas procurou apoio do Egito e de outros aliados, isolando o então presidente líbio Gaddafi, que pressionava pela união com Trípoli em seus planos expansionistas. ${ }^{2}$

2 O presidente Omar Al-Bashir chegou a anunciar em Trípoli, em março de 1990, que em 4anos se levaria a cabo a união entre a Líbia e o Sudão "em direção à união completa do mundo árabe” (AZEVEDO, 1998, p. 70). 
Em abril de 1987, o Exército do Chade invadiu Darfur e destruiu as forças líbias, bem como as milícias árabes de apoio. Os milicianos árabes e muçulmanos armados pela Líbia doutrinados na Jihad, em uma retaliação furiosa, massacraram entre 1000 e 1700 deslocados internos Dinka, em um trem em Ed-Dảien.

Nesse período, outro partido nacionalista árabe, o Tajamu al-Arabi, começou a armar milícias entrando em confronto com outras etnias que tentavam impedi-los. Os Zaghawa se armavam com apoio do Chade e as etnias de Darfur iam se afundando no ódio e no extremismo racial e religioso. Estima-se que o caos armado e o envolvimento em conflitos transfronteiriços em Darfur tenham feito 3000 vítimas em 1988. O mercado de armas leves se massifica fazendo com que, em 1987, um rifle de assalto AK 47 - Kalashnikov pudesse ser adquirido por 40 USD (AFRICA CONFIDENTIAL, 1987). Em 1989, as rupturas, alianças e contrarrupturas de políticos sudaneses com a Líbia e Chade aprofundaram o caos e vários combates entre dezembro de 1988, e fevereiro de 1989, que fizeram 122, 96 e 40 mortos, mas nunca ficou claro quem combatia quem (AFRICA CONFIDENTIAL, 1987). A contagiosa guerra do Chade que trouxe tanta destruição a Darfur, finalmente terminou em dezembro de 1989, quando as forças de Idriss Deby Itno, com apoio líbio e sudanês, a partir de Darfur, entrou em N'Djamena, praticamente sem resistência, depondo o ditador Hissein Habre. A Guerra dos Trinta Anos no Chade tinha finalmente terminado, mas Darfur estava em total caos, a produção agrícola destruída e uma nova ameaça de fome em 1990.

Ibriss Deby, de origem Zaghawa, torna-se o primeiro presidente proveniente do norte do Chade. No entanto, a maioria de sua etnia habita o norte de Darfur e não o Chade. Esse caráter transfronteiriço do Zaghawa será determinante na dinâmica do conflito uma década mais tarde. A primeira tentativa de rebelião em Darfur ocorreu ainda em 1991, mas durou muito pouco. Com o apoio da guerrilha do SPLA (Sudan People's Liberation Army), Daud Bolad organizou uma guerrilha no sul de Darfur, mas foi rapidamente derrotado, capturado e levado para Cartum, onde foi torturado até a morte em janeiro de 1992. O período de calma relativa durou até 1998 quando uma nova seca voltou a atiçar velhas rivalidades. Era uma calma armada, logo, de anos de proliferação de armas leves, em conexão com a ocupação da Líbia, as guerras do Chade e o recomeço do confronto no sul do
Sudão a partir de 1983. Calcula-se que, depois desse período de conflito, 50 mil armas tenham sido abandonadas ou tenham ficado em mãos de ex-milicianos em Darfur.

Em 1994, o governo sudanês, temendo a destruição e descontentamento em Darfur, tenta impor sua soberania na região e a divide em três províncias: Darfur Norte, Oeste e Sul. Incidentes isolados de violência e enfrentamentos entre os Massalit e árabes eram ocasionais durante os anos noventa e ficaram conhecidos como a Guerra Massalit. Em meados de 1998, a seca empurra os árabes pastores do norte para o sul mais cedo, provocando conflitos pelas pastagens. Os ressentimentos e o armamento generalizado geram outra dinâmica nas disputas interétnicas; seis aldeias massalits são incendiadas, 5000 pessoas são deslocadas, 69 massalits e um árabe são mortos. O governo envia um mediador que consegue um acordo entre os lideres tribais. Na tentativa de consolidação do Estado em Darfur, depois dos caóticos anos 80, a reorganização administrativa de 1994 trouxe também a supremacia árabe na administração pública durante o governo fundamentalista islâmico de Bashir/Turabi, a partir de 1989. A arabização em Darfur significou que árabes étnicos foram sendo colocados em posições de poder nas províncias e os mecanismos tradicionais de solução de controvérsias foram sendo substituídos por procedimentos oficias que sistematicamente favoreciam os árabes. O deslocamento de poder provoca ainda mais ressentimento dos lideres tribais dos grupos majoritários, Fur, Zaghawa e Massalit. Em 1999, novamente os nômades chegam mais cedo e o confronto adquire feições de guerra civil interétnica. 125 aldeias massalits são incendiadas ou evacuadas para fugir de ataques, centenas de pessoas são mortas; e vários chefes tribais árabes são assassinados. Cartum envia um interventor e convoca uma conferência de reconciliação que termina com um acordo de compensações mútuas. Isso não impediu o governo de prender e torturar vários intelectuais $\mathrm{e}$ notáveis massalits residentes em Cartum durante a conferência. Os partidos árabes de Darfur evoluem para uma combinação de suprematismo étnico árabe e islamismo radical para se diferenciar dos povos africanos de Darfur igualmente islâmicos. As milícias árabes paramilitares conhecidas como Janjaweed são organizadas nesse período e passaram a aterrorizar as aldeias africanas em um processo de violência endêmica intergrupal (KIERMAN, 2007).

As relações interétnicas com o governo pró-árabe viveram à beira do colapso até o efetivo colapso em 2003, 
quando uma espécie de guerra total intergrupal e do governo com as várias guerrilhas africanas tomou conta da região, com o surgimento do JEM (Justice \& Equality Movement) e SLA (Sudan Liberation Army). Os Janjaweed (jan - bandidos; jaweed - a cavalo) foram constituídos a partir de ações de líderes ligados ao governo recrutando jovens desempregados, ex-pastores desvalidos, criminosos comuns liberados das prisões, soldados desmobilizados do conflito no sul, membros fanáticos do Tajamu Al-Arabi. As milícias étnicas começaram ataques etnicamente motivados uma vez que os Darfuris e outras etnias estão presentes no exército nacional que, ocupados com o processo no Sul, determinaram que o governo tampouco tinha a capacidade de intervir diretamente. No entanto, a estratégia de deslocamento forçado fica clara devido à metodologia seguida. Os ataques eram precedidos de bombardeios aéreos, que eram seguidos de ataques das milícias Janjaweed, em conjunto com os paramilitares das PDF - Popular Defense Force, matando, estuprando e saqueando as aldeias, antes de incendiá-las para evitar o retorno. Esse tipo de estratégia de contrainsurgência em conflitos assimétricos não é novo e se baseia na suposição de apoio popular aos guerrilheiros. O deslocamento de cerca de dois milhões de pessoas se completou em dezembro de 2004, quando os paramilitares se concentraram no combate às milícias. A posse tradicional da terra, válida por cinco anos, pode ter sido um fator adicional na definição da estratégia de expulsão deliberada. A questão do deslocamento forçado é investigada pelo TPI no caso Darfur.

Por outro lado, no vizinho Chade, devido à conexão étnica de Idriss Deby, um Zaghawa étnico, com as comunidades do outro lado da fronteira, o Sudão não tardou a acusá-lo de apoiar as guerrilhas de Darfur. O conflito entre Chade e Sudão (2005-2010) começa por volta de dezembro de 2005, quando o governo do Chade declara "estado de guerra" com o Sudão e chama a uma mobilização geral contra o Front Unitaire pour le Changement Democratique, uma coalizão de forças rebeldes que se rebela contra o governo do presidente Idriss Déby que acusa o Sudão de desestabilizar a região e exportar o conflito de Darfur. Efetivamente foram documentados ataques dos rebeldes chadianos, baseados em território sudanês a campos de refugiados e contra certas tribos do leste do Chade juntamente com milícias Janjaweed. As denúncias do Chade seguiram ao ataque contra a cidade de Adré, perto da fronteira com o Sudão, que causou a morte de dezenas de pessoas. Ambos os governos assinaram um acordo na Arábia Saudita, em maio de 2007, que tentava evitar que os combates em Darfur se generalizassem para dentro do país vizinho, que compartilha uma fronteira de $1000 \mathrm{~km}$. Os dois países se reuniram em Trípoli, em fevereiro de 2006, para acordar a interrupção de qualquer apoio aos respectivos movimentos armados internos, solicitando inclusive à União Africana que monitorasse o acordo. No entanto, antes que tropas da União Africana chegassem à fronteira, os rebeldes lançaram um ousado ataque, com tanques e equipamentos novos, deste território da República Centro-Africana e desde Darfur, alcançando a capital. Os rebeldes lançaram duas ousadas tentativas de tomar a capital nas duas batalhas de N'Djamena, em 13 de abril de 2006 e em 02, 03 e 04 de fevereiro de 2008, nas quais o palácio foi sitiado e o governo só não caiu por causa da presença de um batalhão francês que forneceu importante apoio logístico, e porque os rebeldes, mal organizados, não concluíram a ofensiva e tiveram de se retirar. $\mathrm{O}$ ataque produziu 100 mil refugiados na fronteira com Camarões, e Idriss Deby destruiu com bulldozers os bairros onde viviam as etnias dos combatentes capturados e onde houve combates em ações de punição coletiva aos que supostamente "apoiaram" os rebeldes. No dia 26 de maio, as milícias de Darfur foram à forra e atacaram Omdurman ao lado de Cartum, tomando a cidade por horas. Os dois países romperam relações diplomáticas. O conflito continuou até o primeiro semestre de 2010, quando foi concluído um acordo para cessar as hostilidades, desarmando os rebeldes. O processo de Darfur, no entanto, seguia em impasse nas negociações de Doha, e os rebeldes chadianos se desarmaram e abandonaram Darfur. Idriss Deby decretou uma anistia no segundo semestre de 2010.

\subsection{A AMIS da União Africana (UA)}

Desde 1948, cerca de mais de cinquenta missões de paz intervieram em conflitos africanos, sendo que tropas dos países africanos participaram de quase todas elas, à exceção de mais ou menos dez dessas missões. Diante dessa realidade, com a constituição da União Africana, toda uma renovação institucional operou-se, fazendo com que, baseadas nas experiências anteriores e dos anos noventa, as instituições africanas buscassem ter maior protagonismo na resolução e pacificação em nível regional. As iniciativas da ECOWAS em Serra Leoa e Libéria, 
assim como da SADC (South African Development Community) em Lesoto, tinham contingentes africanos intervindo também no Burundi, Congo (RD) e, recentemente, no Sudão, igualmente no sentido de dar uma maior coerência e aceitação às missões de paz, em países com passado colonial reticentes a aceitar tropas das antigas metrópoles, aumentando também a responsabilidade da África na resolução dos conflitos africanos. Em seu ato constitutivo de julho de 2000, na Conferência de Lomé Togo, a União Africana foi pioneira em adotar a doutrina da intervenção humanitária, legalizando-a numa redação inspirada no "droit d'ingerence." ${ }^{3}$ Igualmente a proposta da constituição de uma força rápida e permanente foi pioneira no contexto africano. A UA também criou uma espécie de conselho de segurança regional, chamado Conselho de Paz e Segurança da UA, que tem a função de tomar medidas urgentes e implementar a política comum de defesa e segurança na África, assim como coordenar as estratégias de prevenção das causas dos conflitos, inclusive o criativo programa da AU para fronteiras. Entre outras funções, o Conselho deve coordenar os programas de reconstrução pós-conflito e desenvolvimento e, coordenar com as organizações regionais africanas. No entanto, uma das primeiras missões da União Africana, a AMIS em Darfur, caiu nas mesmas armadilhas político-operacionais das missões da ONU no começo dos anos noventa, e seu impacto foi muito aquém do necessário. A AMIS atuou em Darfur de 2004 até final de 2007 e, durante mais de três anos, atuou como força pacificadora por mandato corroborado pelo Conselho de Segurança. Na verdade, foi a segunda missão da União Africana depois da missão no Burundi (AMIB - African Mission in Burundi) a partir de 2003, para assegurar o acordo de paz entre as facções em guerra assinado em 2000. A África do Sul contribuiu com a maior parte do contingente de mais de três mil efetivos dessa missão.

O primeiro problema que a AMIS enfrentou foi político e conceitual. As negociações iniciadas pelo Chade, em virtude do imenso influxo de 200 mil refugiados,

3 O direito de ingerência foi defendido por Bernard Kouchner fundador da organização, MSF - Medecins Sans Frontières e Medecins du Monde. No Ato da UA, o artigo 4 trata deste tema: Article 4 - Principes;L'Union africaine fonctionne conformément aux principes suivants: [...] (h) Le droit de l'Union d'intervenir dans un Etat membre sur décision de la Conférence, dans certaines circonstances graves, à savoir: les crimes de guerre, le génocide et les crimes contre l'humanité; foram logo suplantadas pela União Africana que facilitou o Acordo de Paz de Darfur que terminou revelando-se inócuo porque só foi firmado pelo governo do Sudão e uma fração do SLM/A que logo se desintegrou. Mas essa lição já era conhecida; a paz não pode ser unilateral e, em geral, as missões de manutenção da paz não podem atuar onde não há paz para manter. Como muitas missões de manutenção da paz anteriores, a AMIS não atingiu, seus objetivos em Darfur, porque não era suficientemente grande nem equipada para a tarefa operacional colocada e seu mandato era demasiadamente limitado. Contando com apenas oito mil efetivos em uma região desolada e isolada, do tamanho da França, o que tornou impossível proteger a população civil nestas condições, o mandato da missão era direcionado a monitorar a situação e reportar violações ao cessar fogo, mas não estava autorizado a proteger as populações civis de ataques dos Janjaweed. Obviamente, isso limitava severamente sua eficácia, já que sua força total deveria ter atingido 13 mil homens até março de 2006, o que ainda se revelaria totalmente insuficiente. Por outro lado, o custo da missão em um conflito que se prolongava, devido ao contexto do Sudão, combinando com a possibilidade de secessão ao sul, o que implicava em custos que aumentavam a demanda por esforço que os países ocidentais não queriam tocar, a AMIS sofreu de insuficiências operacionais, e era pequena e mal equipada para assegurar o território no qual deveria atuar. Seu mandado era limitado demais e sua intervenção, mesmo quando pôde ocorrer, resultou inócua e de pouca utilidade (EKENGARD, 2006). Igualmente sofreu obstáculos que chamaremos político-conjunturais, uma vez que o acordo de paz resultou limitado demais e o retorno às hostilidades comprometeu seu objetivo. Portanto, a continuidade da crise humanitária, mesmo com a presença da AMIS, levou à outra solução inédita - a UNAMID -, que veremos adiante.

\section{A EUFOR e a MINURCAT: a regionalização da crise humanitária}

A situação no Sudão produziu várias missões de paz e tem sido o país com maior presença de tropas estrangeiras autorizadas pela ONU. O conflito de Darfur produziu também um aprofundamento nas mudanças que atingiram as missões de paz em geral, e da Organização das Nações Unidas em particular. No plano institucional, a EUFOR foi estabelecida pelo Comitê Político 
e de Segurança da União Europeia em 13 de fevereiro de $2008,{ }^{4}$ logo depois da segunda batalha de N'Djamena no início de fevereiro de 2008, socorrendo o Chade sob ataque dos rebeldes "supostamente" apoiados pelo Sudão. Os entraves no conselho de segurança podem ter determinado uma missão europeia que passou seu comando para a ONU somente em 15 de março de 2009, para a MINURCAT, apenas estabelecida pela Resolução 1861, em 2009, com o mesmo raio de atuação, o Chade e a República Centro Africana. O mandato da EUFOR se encontra em consonância com as inovações das doutrinas da segurança humana e da responsabilidade de proteger, que pretende dar ao conceito de segurança uma dimensão humana (VIOTTI, 2004). O fato de atuar em um país vizinho, onde fundamentalmente há uma crise humanitária, faz com que a manifestação desse princípio não assuma sua forma mais militar e intervencionista, mas inequivocamente se dão passos nesse sentido. $\mathrm{O}$ mandato da EUFOR demonstra claramente uma combinação do militar com o humanitário aprofundamento e o rompimento com a tradicional neutralidade das ações humanitárias.

A EUFOR nasce com mandato para:

- proteger civis em perigo, particularmente refugiados e pessoas deslocadas;

- facilitar a prestação de assistência humanitária, garantir a liberdade de movimento dos trabalhadores humanitários e ajudar a melhorar as condições de segurança nas áreas de operação; e

- contribuir para a proteção do pessoal da ONU, instalações, premissas e equipamentos, e assegurar a segurança e liberdade de movimento do pessoal, e do pessoal associado.

Na prática, organizações neutras como o Comitê Internacional da Cruz Vermelha possuem crescentes dificuldades de atuar devido ao seu ortodoxo neutralismo, uma vez que, efetivamente, apesar dos reais problemas de segurança, ocorre uma militarização da assistência humanitária. No entanto, sobretudo no pós-guerra fria,

4 Décision Chad-1-2008 Du Comité Politique et de Securité du 13 Févier 2008, relative à l'aceptation de contributions d'Etats tiers à l'operation militaire de l'Union Européenne en Republique du Tchad et en Republique Centrafricaine, in Journal Officiel de l'Union Européenne, 29.02.2008, p 56-64fr. os ataques ao pessoal humanitário e as violações da neutralidade das missões de assistência humanitária têm sido uma constante. O mandato para proteger refugiados, deslocados internos e o pessoal humanitário era extremante necessário, uma vez que, por meio da desguarnecida fronteira desértica e plana entre Chade e Sudão ocorriam incursões das milícias chadianas, e atacavam os campos de refugiados sudaneses em território chadiano. Também povoados de fronteira, considerados bastiões de apoio dos rebeldes sudaneses de Darfur eram atacados, gerando nova população deslocada do Chade para os campos de refugiados sudaneses em território chadiano, ou seja, em um emaranhado de conflitos e atores em que a população civil deslocada e refugiada era constantemente vitimizada. Por outro lado, os ataques às missões de assistência humanitária foram crescentes e inequívocos. A sua politização, como um suposto "apoio camuflado" do Ocidente aos rebeldes, devido à paranoia de governos isolados e violentos, trouxe os trágicos sequestros, expulsões e assassinatos de trabalhadores humanitários. Em abril de 2008, o diretor de Save the Children, no Chade, foi sumariamente executado por rebeldes chadianos. Seu motorista foi poupado e nada foi roubado, em um claro ataque seletivo direcionado contra o trabalho humanitário. Em maio de 2008, os rebeldes sudaneses chegaram à Omdurman, a lendária capital histórica do Sudão, situada na margem direita do Nilo Branco, ao lado de Cartum. O Sudão e o Chade viveram uma guerra indireta até princípios de 2011. Em uma reacomodação estratégica, o governo sudanês, para fortalecer a combalida posição do governo em Darfur, preferiu a diplomacia à guerra em várias frentes.

Quando a espiral de conflito em Darfur transbordou para o Chade e para a República Centro Africana, já nos primeiros anos do conflito, 250 mil darfuris tinham cruzado a fronteira com o Chade buscando refúgio contra os ataques sistemáticos às aldeias “africanas" de Darfur. A esse imenso contingente de refugiados se juntaram cerca de 50 mil refugiados da República Centro Africana, vítimas do mesmo banditismo armado proveniente de Darfur que, além do mais, encontraram na mesma região cerca de 180 mil deslocados internos chadianos, devido à guerra civil no leste do país, contíguo às províncias sudanesas de Darfur Oeste, Norte e Sul.

\subsection{O componente policial e civil}

A situação estava afetando internamente dois países em particular, mas devido ao conflito, um terceiro 
país levou à particular fragmentação da missão, uma vez que se pensou em um componente civil e policial prioritariamente e não um componente militar, uma vez que não se tratava de uma operação de paz e sim de fortalecimento das capacidades dos estados envolvidos em prover segurança e manter a ordem. A Resolução 1778 de 25 de setembro de 2007 do Conselho de Segurança possui esse enfoque buscando criar capacidades locais de policiamento, evitar recrutamento de crianças e proteger as mulheres da violência sistemática de gênero pelos grupos armados no nordeste da República Centro-Africana e no leste do Chade. Nesse sentido, a EUFOR tinha esse componente, assim como inicialmente a MINURCAT, com 300 policiais e 50 oficiais, bem como pessoal civil. O Conselho de Segurança resolveu apoiar a iniciativa do Chade na criação da Police Tchadienne pour la Protection Humanitaire (PTPH), especialmente encarregada de atuar nos campos e garantir sua segurança.

O componente militar propriamente dito foi estabelecido com a Resolução 1861 de janeiro de 2009, quando o Conselho notou a continuidade das atividades armadas e ataques contra a população civil no leste do Chade e nordeste da República Centro Africana relacionados com o conflito em Darfur no oeste do Sudão. Nessa Resolução, o Conselho de Segurança autoriza o deslocamento do componente militar da MINURCAT para seguir a EUFOR em ambos os países ao final do seu mandato, em março de 2009, transferindo sua autoridade entre a EUFOR e o componente militar da MINURCAT, adicionando 5200 efetivos militares.

\subsection{0 pedido do Chade para que a MINURCAT se re- tire e o fim do mandato}

Em janeiro de 2010, o governo do Chade solicita a retirada da MINURCAT de seu território a partir de 15 de março, respondendo a interesses ligados à sua negociação bilateral com o Sudão no sentido de normalizar suas relações bilaterais. Não se descarta pressões do Sudão para isso, ainda que não se possa confirmar historicamente. No entanto, após intensas negociações, chegou-se a um acordo para a extensão da MINURCAT até 31 de dezembro de 2010, com um mandato revisado no qual a República do Chade se comprometeu a exercer sua responsabilidade soberana de proteger a população civil no leste do Chade, incluindo os refugiados, pessoas internamente deslocadas e as comunidades receptoras, conforme suas obrigações perante o direito internacional. Final- mente, em 25 de maio de 2010, o Conselho de Segurança, por meio da Resolução 1923, revisou o mandato transferindo para o governo do Chade a total responsabilidade pela proteção de civis, determinando que a MINURCAT começasse gradualmente a retirar suas tropas a partir de maio. O novo mandato permitia ainda que o componente civil continuasse a desenvolver planos para a sustentabilidade da proteção de civis e outras tarefas de manutenção da paz após a total retirada da MINURCAT, em 31 de dezembro de 2010, o que efetivamente ocorreu, a partir de retiradas parciais, que começaram em julho de 2010.

\subsection{Missão cumprida, mandato concluído}

A MINURCAT, durante esse período final, transpassou seus programas para o governo do Chade e para as agências da ONU operando no país. Tais programas incluem direitos humanos, governança, proteção da infância e violência de gênero e, principalmente, o programa de retorno dos deslocados internos, que somavam milhares de pessoas, sobretudo no leste do país. Segundo o governo do Chade, as unidades chamadas Détachement Intégré de Sécurité (DIS), uma força integrada treinada pela ONU se encarregaria da proteção de civis após a retirada da MINURCAT.

No informe ao Conselho de Segurança, o Secretário Geral notou o ineditismo da MINURCAT como uma missão exclusivamente humanitária, dedicada somente à proteção da população civil, incluindo os refugiados e deslocados internos e a assegurar condições apropriadas para a provisão de assistência humanitária. A MINURCAT, portanto, não teve um mandato político per se, tendo sido fundamentalmente humanitária. Também foi uma missão curta que realizou seu mandato em menos de quatro anos. No final de seu mandato, a MINURCAT continuou a assistir as unidades integradas do Chade, fazendo a ligação com outros agentes de segurança no Chade e na República Centro Africana e, finalmente, a assistir na relocalização dos campos para longe da fronteira. Conforme previsto, a MINURCAT completou seu mandato em 31 de dezembro de 2010.

\section{Unamid: a primeira missão híbrida}

A UNAMID foi estabelecida pelo Conselho de Segurança, pela Resolução 1769 em 2007 sob o capítulo VII da Carta da ONU, e foi constituída como missão 
híbrida da ONU - União Africana, com mandato para implementar os acordos de paz em Darfur. O diferencial desta missão é a autorização para o uso da força em virtude de seu embasamento no capítulo VII. O deslocamento da UNAMID foi totalmente atrasado por entraves do governo do Sudão e, no fim de 2008, dos 26 mil efetivos previstos, apenas 9178 tropas foram deslocadas. Em fevereiro de 2011, dos 26 mil autorizados, a UNAMID havia colocado 23 mil no terreno.

Ao perceber o fracasso da AMIS, para garantir a segurança da população civil e avançar no processo de paz em Darfur, devido ao seu tamanho e mandato inadequados, o Conselho de Segurança votou a Resolução 1706 determinando o deslocamento de uma missão para Darfur substituindo a AMIS. No entanto, tal operação foi totalmente bloqueada pela oposição do governo do Sudão, com o argumento de que a ONU era um instrumento das grandes potências que almejavam recolonizar o Sudão, expropriando-o de suas riquezas, sobretudo, o petróleo (PRUNIER, 2007).

A história da UNAMID é a parte da historia das contradições crônicas que envolveram os conflitos sudaneses e seu isolamento internacional. Quando soou o alarme sobre a crise de Darfur, a comunidade internacional estava profundamente envolvida no Sudão, em plena negociação para colocar um termo ao mais antigo conflito africano, que já ocorria no país, opondo o Sul e o Norte. No primeiro momento, o Sudão teve força para impor uma missão da União Africana, com mandado de observar e reportar, o que terminou sendo uma missão inócua. O parcial e efêmero acordo de Paz de Darfur, assinado em maio de 2006, desencadeou esforços complementares para incluir os grupos não signatários. A violência, no entanto, nunca parou. A solução do hibridismo veio como uma solução conciliatória à oposição do governo sudanês a uma missão da ONU e a necessidade de uma intervenção mais efetiva em Darfur. Em 16 de novembro de 2006, em Addis Abeba, na Etiópia, conduzidas pelos membros permanentes do Conselho de Segurança e pelo ex-Secretário Geral Kofi Annan, com representantes do Governo do Sudão, a União Africana e outros atores influentes na região, acordou-se finalmente com o plano desenvolvido pelo Department of Peacekeeping Operations (DPKO) para um aumento em três etapas da AMIS e sua substituição por uma inédita e híbrida União Africana/ONU, missão de manutenção da paz em Darfur. No entanto, não foi até junho que a pressão internacional resultou na aceitação, pelo governo islâmico de Cartum, desta força em junho de 2007. Portanto, a Resolução 1769 do Conselho de Segurança autorizou o estabelecimento da UNAMID atuando sob o capítulo VII por um período inicial de 12 meses, formalmente tomando o comando da operação em 31 de dezembro de 2007.

A partir daí, estabeleceram-se os quartéis generais de El Fasher, El Geneina e Nyala, respectivamente capitais dos estados de Darfur Norte, Oeste e Sul, com presença em outras localidades dos três estados de Darfur. Em sua máxima força estabelecida pelo Conselho, de quase 20 mil efetivos militares e seis mil efetivos policiais, a UNAMID foi a maior missão de paz estabelecida na história da ONU. No entanto, ela não chegou a deslocar todos os seus efetivos devido à falta de cooperação do governo, atrasos dos países contribuintes, falta de segurança e os desafios logísticos de Darfur, uma região imensa, semidesértica, remota e com infraestrutura precária. A composição da UNAMID respeita as preocupações do governo do Sudão, mantendo um caráter predominante africano, no entanto, já com maior capacidade de cumprir seu mandato. Egito, Etiópia, Gâmbia, Quênia, Nigéria, Ruanda, Senegal e África do Sul foram alguns dos países africanos que contribuíram com tropas para a UNAMID. A missão continuou a sofrer de limitações crônicas em tropas e equipamentos, tendo levado o novo Secretário Geral Ban Ki-Mun a apelar por apoio à missão, sobretudo por tropas e equipamentos de aviação, principalmente helicópteros, para provê-la com as capacidades necessárias para cumprir seu mandato e proteger a população civil e deslocada, minimizar a violência e facilitar a assistência humanitária em Darfur.

\subsection{O maior mandato da face da terra}

O essencial do mandato da UNAMID é a proteção da população civil, mas também o Conselho de Segurança estabeleceu tarefas ambiciosas demais e multidimensionais como contribuir com a assistência humanitária, verificar a implementação dos acordos, auxiliar o processo político, promover os direitos humanos, o estado de direito e monitorar a situação das fronteiras com o Chade e a República Centro-Africana (BELLAMY; WILLIAMS, 2010). Atuando sob o capítulo VII da Carta das Nações Unidas, o mandato estabelecido pela Resolução 1769, de 31 de julho de 2007, para que a UNAMID tomasse as ações necessárias em suas áreas de atuação para, em linhas gerais: 
Proteger o seu pessoal, instalações e equipamentos, assegurar a liberdade de movimento dos trabalhadores humanitários e de seu próprio pessoal;

Apoiar a implementação efetiva e tempestiva do Acordo de Paz de Darfur, prevenir sua violação e ataques armados, proteger a população civil sem prejuízo da responsabilidade do governo do Sudão.

No entanto, o Conselho de Segurança decidiu também que o mandato da UNAMID deveria incluir os pontos constantes dos parágrafos 54 e 55 do informe do Secretário Geral e do presidente da Comissão da União Africana, de 5 de junho de 2007, o que significou uma imensa ampliação. Os primeiros oito pontos do mandato se referem a tarefas relacionadas às funções gerais da missão como a garantia de segurança para a assistência humanitária, proteção de populações civis, monitoramento dos acordos de cessar-fogo e implementação do Acordo de Paz; apoiar o processo político para alcançar um acordo de paz geral e inclusivo mediado pela ONU e a União Africana; contribuir com um ambiente seguro para a reconstrução econômica e o retorno dos deslocados e refugiados; contribuir para a proteção aos direitos humanos; a promoção do estado de direito incluindo o fortalecimento de um poder judiciário independente e o sistema prisional; assim como o marco legal e, finalmente, o monitoramento da segurança das fronteiras com o Chade e a República Centro Africana.

Apenas com esse pacote de tarefas, incluindo direitos humanos, segurança de fronteiras e estado de direito, a missão já teria seu mandato consideravelmente ampliado no sentido de reconstrução das estruturas do estado na região de Darfur, o que dificilmente se lograria sem a participação do país hospedeiro e, sendo um processo ligado ao desenvolvimento nacional, com sérias limitações à ação em nível regional. No entanto, o mandado foi ainda mais ampliado, conforme quatro conjuntos de tarefas multidimensionais com vários pontos de complexa implementação e administração.

\subsection{Apoio ao processo de paz e bons ofícios}

Nesse conjunto de atribuições, a UNAMID foi encarregada de apoiar o processo de paz e os esforços de mediação da União Africana, enviados especiais e Nações Unidas; apoiar a implementação do Acordo de Paz de Darfur e acordos subsequentes; prover apoio logístico e técnico aos órgãos criados pelos acordos de paz; facilitar a preparação e condução do diálogo e consultas estipulados nos acordos; assistir na preparação e condução do referendum previsto no acordo; assegurar a implementação complementar de todos os acordos de paz do Sudão e da constituição provisória; fazer a ligação com a UNMIS, União Africana e outros atores na implementação complementar dos acordos de paz no Sudão e o mandado da própria missão.

\subsection{Segurança}

O conjunto de atribuições relacionadas à segurança possui onze pontos e tarefas extremamente complexas e difíceis, começando pela descrição do primeiro ponto: restabelecimento da confiança e prevenção da violência por meio de patrulhas, zonas de segurança, monitoramento da retiradas de armas de longo alcance e deslocamento da polícia híbrida, em áreas de concentração de população deslocada, nas zonas de segurança e de isolamento, ao longo de rotas de migração e outras de uso vital. Logo, a descrição continua com outras importantes e complexas tarefas: monitorar, investigar e informar sobre as violações do Acordo e do cessar-fogo; monitorar, verificar e promover o desarmamento dos Janjaweed e outras milícias; coordenar o apoio logístico para movimentos que não envolvam combate; assistir ao estabelecimento de um programa de DDR (Desmobilização, Desarmamento e Reintegração) previsto no Acordo de Paz de Darfur; contribuir com a criação das condições de segurança necessárias para a assistência humanitária e facilitar o retorno da população deslocada; em suas áreas de presença e dentro das possibilidades, proteger o pessoal da missão, instalações e equipamento, assegurar a mobilidade do pessoal e dos trabalhadores humanitários e outros atores do processo de paz, proteger civis sob iminente risco de violência física e prevenir ataques; monitorar, por meio de patrulhas, as atividades policiais nos campos para deslocados internos; apoiar, o estabelecimento e treinamento das policias comunitárias nos campos de deslocados internos, o desenvolvimento institucional e as capacidades das policias locais de acordo com os padrões internacionais de responsabilidade e respeito aos direitos humanos; apoiar os esforços do governo em manter a ordem e capacitar as forcas da ordem sudanesas; prover apoio técnico a Mine-action, e capacitação em remoção de minas, previstos no acordo de paz. 


\subsection{Direitos Humanos e estado de direito}

Neste ponto, a operação, ainda que mais modestamente, aparece como um agente de refundação do Estado com tarefas praticamente ilimitadas, começando pela implementação dessas provisões no Acordo de Paz e outros acordos posteriores para criar um ambiente propício para o respeito aos direitos humanos e o estado de direito. Entre os demais objetivos se encontram outros não menos ambiciosos: assistir as partes e autoridades locais em seus esforços de assegurar a transferência de recursos de forma equitativa do governo federal aos estados de Darfur; implementar planos de reconstrução e os acordos sobre o uso da terra e indenizações; apoiar as partes em re-estruturar e capacitar a polícia de Darfur, incluindo monitoramento, treinamento e patrulhas conjuntas; promover o estado de direito, inclusive por meio da construção institucional, fortalecimento das capacidades locais e combate à impunidade; assegurar capacidade em direitos humanos e gênero para promover os direitos humanos em Darfur, particularmente dos grupos mais vulneráveis; capacitar as mulheres para participarem no processo de paz, incluindo a representação política, empoderamento econômico e proteção contra a violência de gênero; e apoiar a implementação das disposições com relação aos direitos das crianças.

\subsection{Justiça sem paz, ou paz por meio da justiça: a atuação do TPI em Darfur}

A negociação da impunidade em processos de transição de períodos de repressão violenta ou conflito foi, durante décadas, uma prática corrente; e anistias gerais e acordos foram parte do pacote de normalização que criou uma falsa dicotomia entre justiça e pacificação. Essa realidade começa a mudar com os tribunais ad hoc para Iugoslávia e Ruanda e, posteriormente, com o Tribunal Penal Internacional (TPI). A atuação do TPI introduziu um elemento novo em Darfur, uma vez que a jurisdição do TPI não é negociável pelos atores e aliena a imputabilidade penal do processo de paz. A situação de Darfur foi referida de forma surpreendente pelo Conselho de Segurança ao TPI em março de 2005. Já em fevereiro de 2007, o procurador do TPI considerou ter evidências suficientes para solicitar um mandato de prisão contra duas figuras fundamentais: o Ministro do Interior, durante a deflagração do conflito, e um dos chefes da milícia Jan- jaweed (INTERNATIONAL CRIMINAL COURT, 2007). Esses casos já tiveram um impacto amargo que, no entanto, não se comparou com a intensa friç̧ão desencadeada pela emissão do mandado de prisão contra o presidente sudanês Omar al-Bashir em março de 2009, o que provocou verdadeira convulsão diplomática no processo de Darfur (INTERNATIONAL CRIMINAL COURT, 2009). O presidente foi acusado em cinco denúncias por crimes contra a humanidade: assassinato, extermínio, deslocamento forçado, tortura e estupro. Também responde por duas denúncias por crimes de guerra, sendo ataques contra população civil e pilhagem.

Imediatamente o governo do Sudão expulsou 13 das principais ONGs que atuavam fornecendo assistência humanitária vital em Darfur, colocando milhares de vidas em risco. Naquele momento, aproximadamente 4,7 milhões de pessoas em Darfur se beneficiavam de ajuda internacional, sendo que destas, 2,7 milhões de deslocados internos diretamente dependentes.

O risco de um novo fluxo para o Chade e um aumento da mortalidade foi iminente, uma vez que 1,1 milhão ficaria sem comida, 1,5 milhão sem cuidados médicos e um milhão sem água potável. A situação foi precariamente revertida por meio da substituição por ONGs locais, mas o processo de paz ficou mais complicado e a hostilidade contra os trabalhadores humanitários e a missão de paz aumentou consideravelmente, com atrasos nas autorizações e acusações verbais frequentes. Em julho de 2010, o TPI emitiu outra ordem de arresto contra Bashir por genocídio, em três das cinco tipificações desse crime: matar membros do grupo, causar dano físico ou mental grave e impor condições de vida calculadas a levar a destruição do grupo. Este último diretamente relacionado ao problema da assistência humanitária. $\mathrm{O}$ governo emitiu uma nova onda de expulsões de trabalhadores humanitários no mesmo mês, que se repetiram de forma intermitente. Em maio de 2009 e junho de 2010, o TPI acusou também os rebeldes Bahar Idriss Abu Garda, do United Resistance Fron" (INTERNATIONAL CRIMINAL COURT, 2009a) e Saleh Mohammed Jerbo Jamus e Abdallah Banda Abakaer Nourain, ambos atualmente no Justice and Equality Movement, em duas denúncias por crimes de guerra: ataque deliberado à missão de manutenção da paz e pilhagem (INTERNATIONAL CRIMI- 
NAL COURT, 2009b)5. O governo do Sudão chegou a acusar, em 2011, que a UNAMID apoiava diretamente os rebeldes, mantendo alto nível de tensão (AL-SAHAFA, 2011).

\section{Conclusão}

Ao analisar o retorno das missões multidimensionais durante o conflito de Darfur, com mandatos de tal amplitude e complexidade, principalmente com relação à UNAMID, tem-se a impressão de que uma missão de paz pode transformar historicamente um país, ou nesse caso, uma região. Cria-se a falsa noção de refundação do Estado sobre o qual a missão atua, no entanto, pode-se notar que o mandato, ainda que amplo, limita-se a apoiar, promover e assistir na construção de capacidades locais, o que reduz consideravelmente sua amplitude, transformando a missão em um ator, entre outros, no processo de construção política da paz. Esse processo de introspecção na realidade local e apoio aos atores locais pode resultar em maiores riscos de politização, mas parece oferecer melhores perspectivas em longo prazo.

Por outro lado, todas as tarefas relacionadas aos direitos humanos e fortalecimento das instituições locais estão limitadas pela relação com as autoridades locais. Em Darfur, com as inúmeras fricções com a comunidade internacional, resultantes do processo de paz no sul, afetam de forma qualitativa o processo de paz e o funcionamento da missão. Essa missão, além de ineditamente híbrida, enfrenta o desafio igualmente inédito de atuar em um país em meio a outro conflito e a outra missão de paz, envolto em uma região convulsionada pelo transbordamento do conflito com outras missões de paz. Igualmente, existem as limitações de um processo de paz e da transformação institucional em um contexto regional, extremamente dependente dos desenvolvimentos nacionais, em geral, e do conflito no sul em particular.

\footnotetext{
5 Ainda respondem no Tribunal Penal Internacional, por crimes previstos no Estatuto de Roma, os seguintes cidadãos sudaneses: Saleh Mohammed Jerbo Jamus, que responde por crimes previstos no Artigo 25 (Responsabilidade Criminal Individual) , Parágrafo 3, “alínea a” e, desde 2012, o atual Ministro da Defesa do Sudão Abdel Raheem Muhammad Hussein, pelos crimes previstos no Artigo 25 (Responsabilidade Criminal Individual) , Parágrafo 3, "alínea a") e por cumplicidade nos crimes previstos pelos Artigos $7^{\circ}$. e $8^{\circ}$. do Estatuto de Roma. Ver INTERNATIONAL CRIMINAL COURT, 2012.
}

Tendemos a concluir que, ainda que pareçam amplos demais, os mandatos complexos são inevitáveis para responder a conflitos complexos. Talvez formas de operacionalizá-los mais práticas seriam ajustes necessários, mas que envolvam um aprendizado em campo, além de estudos mais aprofundados sobre a natureza dos conflitos em geral, e dos conflitos étnicos em particular.

No entanto, talvez nada tenha afetado a missão e o cumprimento de seu mandato mais que a atuação do Tribunal Penal Internacional. O impacto pode ser contraditório no começo, porém, começa a sentar as bases de uma regra geral, na qual a impunidade está excluída do processo de paz, o que abrirá perspectivas de pacificação mais sólida em longo prazo. Outros analistas supõem que os conflitos podem se tornar mais cruentos e prolongados como um efeito colateral do fim da impunidade. Não saberemos senão em muitos anos; no entanto, os efeitos iniciais, sobretudo sobre a assistência humanitária, foram de hostilidade e assédio sistemático. Historicamente é um processo muito novo que não permite conclusões peremptórias, pelo seu ineditismo. No entanto, o que é inequívoco é que a justiça internacional possui um impacto inegável, que pode ter um poderoso efeito constrangedor da violência em massa, mas que até se afirmar, poderá levar, talvez, a processos de paz mais truncados e difíceis.

Outro aspecto que salta aos olhos no conflito de Darfur foi a forma errática e hesitante com que a comunidade internacional respondeu à maior crise humanitária do século. A alta mortalidade e a inércia com relação ao conflito estão diretamente relacionadas à conjuntura internacional e às características do Sudão. Estima-se que pelo menos 300 mil pessoas tenham morrido e dois milhões e meio tenham sido forçadamente deslocadas pelo conflito desde 2003. Os ataques sistemáticos contra a população civil, o deslocamento forçado, assassinatos, estupros e saque as aldeias pelas milícias pro - governo Janjaweed, foram uma constante. As tropas e a aviação governamental estiveram diretamente envolvidas no conflito. No entanto, a resposta da comunidade internacional não refletiu o consenso com relação à chamada intervenção humanitária, por vários fatores, dos quais podemos citar, principalmente, a mudança da conjuntura internacional após a controversa intervenção em Kosovo e os atentados de 11 de setembro, que terminaram por deslocar o foco dos principais problemas de segurança internacional, das crises humanitárias gerais ao problema localizado do terrorismo. 
As guerras do Afeganistão e do Iraque com seus imensos desafios logísticos comprometeram o interesse de potências centrais como Estados Unidos e Reino Unido. Igualmente o intervencionismo militar foi colocado em cheque com o mal estar gerado em Kosovo e que ainda era muito recente. No entanto, contraditoriamente, a paz no Sul pode ter sido o maior obstáculo a uma decidida intervenção em Darfur. A comunidade internacional estava extremamente empenhada em facilitar a paz no Sul, o conflito mais antigo do continente africano, e a deflagração de Darfur exauriu os espaços diplomáticos e limitou a margem de atuação entre o Sudão e a comunidade internacional. A impotência da AMIS está diretamente ligada a essa correlação de forças desfavorável em uma espécie de barganha sinistra. Uma paz por uma nova guerra. O papel da China é inegável. O presidente chinês Hu Jintao visitou o Sudão em 2006 e falou apenas de negócios, clamando no Conselho de Segurança respeito pela soberania do Sudão. O silenciar da China se parece demais à cumplicidade para ser ignorado.

Finalmente com relação aos supostos enigmas do conflito de Darfur, podemos dizer que todos são verdadeiros, porém apenas parte da verdade. A desertificação no Sahel existe e os conflitos étnicos também. No entanto, agricultores e pastores pobres não podem conduzir bombardeios aéreos e armar milhares de milicianos com fuzis automáticos e armamento pesado. Conflitos localizados entre tribos não provocam o deslocamento de dois milhões de pessoas. Somente um Estado nacional teria a capacidade de causar uma guerra civil dessa magnitude. O governo do Sudão não inventou os conflitos étnicos, no entanto, os elevou a uma dimensão somente possível com operações militares de grande envergadura.

O mito dos conflitos tribais ronda as análises dos conflitos africanos desde a Somália e Ruanda, nos anos noventa. No entanto, ele só tem provocado confusão e inépcia das respostas preconceituosas. A África, em meio à sua diversidade étnica e cultural, suas tribos e tradições, herdou e construiu estados nacionais, com fronteiras, instituições modernas e exércitos. A construção de estados inclusivos, com garantias para as minorias e diversidade, poderá ser um passo para tirá-la do pântano do suprematismo étnico ou religioso de elites obtusas e violentas. Esta tem sido a síndrome do Sudão desde a independência, a afirmação forçada de uma identidade inexistente que o levou a oscilar entre o suprematismo (nacionalismo) árabe, e o fundamentalismo religioso que levaram a guerras, à pobreza endêmica e à fome. Até hoje ninguém foi capaz de reconhecer a realidade, a diversidade do povo do Sudão e sua necessidade de inclusão e desenvolvimento.

\section{Referências}

ARMSTRONG, Karen. Em nome de Deus, o fundamentalismo no judaísmo, no cristianismo e no islamismo. São Paulo: Cia das Letras, 2001.

AZEVEDO, Mario J. Roots of violence, A history of war in Chad. London: Routledge, 1998.

BELLAMY, Alex J.; WILLIAMS, Paul. Understanding peacekeeping. 2. ed. Polity Press, 2010.

EKENGARD, Avid. The African Union Mission in Sudan (AMIS), experiences and lessons learned, FOI. Stockholm: Swedish Defence Research Agency, Division of Defence Analysis, 2006.

EVANS, Gareth. The responsibility to protect, ending mass atrocities crimes once and for all. Washington DC: Brookings Institution Press, 2008

INTERNATIONAL COMMISSION ON INTERVENTION AND STATE SOVEREIGNTY - ICISS. Report of the International Commission on Intervention and State Sovereignty, The Responsibility to Protect, dezembro 2001.

INTERNATIONAL COMMISSION ON INTERVENTION AND STATE SOVEREIGNTY - ICISS-Report of the International Commission on Intervention and State Sovereignty. The Responsibility to Protect, dezembro, 2001.

INTERNATIONAL CRIMINAL COURT. ICC-02/0501/07: Case The Prosecutor v. Ahmad Muhammad Harun ("Ahmad Harun") and Ali Muhammad Ali AbdAl-Rahman ("Ali Kushayb"). Disponível em: http:// www.icc.cpi.int/EN_Menus/ICC/Situations\%20and\%20 Cases/Situations/Situation\%20ICC\%200205/Pages/ situation\%20icc-0205.aspx. Acesso em: maio de 2011.

INTERNATIONAL CRIMINAL COURT. ICC-02/0501/09: Case The Prosecutor v. Omar Hassan Ahmad Al Bashir, 2009. Disponível em: http://www.icc.cpi.int/ EN_Menus/ICC/Situations\%20and\%20Cases/Situations/ Situation\%20ICC\%200205/Pages/situation\%20icc-0205. aspx. Acesso em: maio de 2011. 
INTERNATIONAL CRIMINAL COURT. ICC-02/0502/09: Case The Prosecutor v. Bahar Idriss Abu Garda, 2009a. Disponível em: http://www.icc-cpi.int/EN_ Menus/ICC/Situations\%20and\%20Cases/Situations/ Situation\%20ICC\%200205/Pages/situation\%20icc-0205. aspx. Acesso em: maio de 2011.

INTERNATIONAL CRIMINAL COURT. ICC02/05-03/09: Case The Prosecutor v. Abdallah Banda Abakaer Nourain and Saleh Mohammed Jerbo, 2009b. Disponível em: http://www.icc-cpi.int/EN_Menus/ICC/ Situations\%20and\%20Cases/Situations/Situation\%20 ICC\%200205/Pages/situation\%20icc-0205.aspx. Acesso em maio de 2011.

INTERNATIONAL CRIMINAL COURT. ICC-02/0501/12: Case The Prosecutor v. Abdel Raheem Muhammad Hussein, 2012. Disponível em: http://www.icc.cpi.int/ EN_Menus/ICC/Situations\%20and\%20Cases/Situations/ Situation\%20ICC\%200205/Pages/situation\%20icc-0205. aspx. Acesso em maio de 2013.

JOHNSON, Douglas H. The root causes of Sudan's civil wars. The International Africa Institute, Nairobi: James Currey- Oxford, Fountain publishers-Kampala, Indiana University Press, East African Educational Publishers, 2006.

JORNAL AL-SAHAFA. Cartum, abril de 2011.

KAROL, Josef Krotki. Demographic survey of Sudan, in the population of Sudan. Report to the sixth Annual Conference. Khartoum: Philosofical Society of Sudan, 1958.

KIERMAN, Benedict. Blood and soil, A world history of genocide and extermination from Sparta to Darfur. New Haven \& London: Yale University Press, 2007.
KISSI, Edward. Genocide in Cambodia and Ethiopia. In: GELATELLY, Robert; KIERMAN, Ben (Ed.). The specter of genocide. Mass murder in historical perspective. Cambridge: Cambridge University Press, 2003.

ORGANIZAÇÃO DAS NAÇÕES UNIDAS. Resolução do Conselho de Segurança da ONU 1593, de 31 de março de 2005. Disponível em: <http://daccessdds.un.org/ $\mathrm{doc/UNDOC/GEN/N05/292/73/PDF/N0529273.}$ pdf?OpenElement $>$. Acesso em: 08 jun. 2009.

PRUNIER, Gérard. Darfur, the ambiguous genocide. New York: Cornell University Press, Ithaka, 2007.

PRUNIER, Gérard. Genocide in Darfu. Le Monde Diplomatique, Reino Unido, mar. 2007. Disponível em : http://mondediplo.com/2007/03/08darfur. Acesso em 5 mai 2011.

UNIVERSITY FOR PEACE. Environmental degradation as a cause of conflict: conference proceedings. Khartoum, December 2004.

VIOTTI, Aurélio Romanini de Abranches. Ações humanitárias pelo Conselho de Segurança: entre a Cruz Vermelha e Clausewitz. Brasília: FUNAG, 2004.

WAAL, Alex de. FLINT, Julie. Darfur, a new history of a long war. New York: Zed Books, 2008.

WAAL, Alex de. Sudan: what kind of state? What kind of crisis? Occasional Paper, Social Science Research Council The Editor, Crisis States Research Centre. London: LSE, 2007 